\title{
ANALISIS KRITIS HUKUM TERHADAP KEDUDUKAN AHLI WARIS PENGGANTI DALAM HUKUM KELUARGA ISLAM DI INDONESIA
}

\author{
Aang Abdul Aziz \\ Fakultas Syariah dan Hukum UIN Sunan Gunung Djati Bandung \\ Email : aangabdulaziz24@gmail.com
}

\begin{abstract}
The substitute heir (plaatsvervulling) is not explicitly mentioned in the Qur'an and has opened various interpretations in Islamic inheritance law. One of them is the opinion issued by M. Yahya Harahap that legitimate Indonesian Law perspective on substitute heir. The opinion stated that grandchildren can replace their parent's position as an heir of their grandfather, if their parent deceased before the grandfather. This interpretation is different from inheritance law in other Islamic countries. This paper is aimed to discuss the background and istinbath al hukmi used by M. Yahya Harahap in describing substitute heirs. With critical study on various library materials and interview, it was found that M. Yahya Harahap's reason to determine the substitute heirs was influenced by customary law, and apllied 'urf and istilah (Mashlah Mursalah) as istinbath hukmi.
\end{abstract}

\section{Key words:}

istinbath al hukmi, inheritance law, wasiat wajibah, substitute heir

\begin{abstract}
Abstrak
Tidak disebutkannya ahli waris pengganti dalam Al-Quran secara tersurat telah membuka berbagai penafsiran dalam hukum waris Islam. Salah satunya adalah pendapat yang dikeluarkan oleh M. Yahya Harahap. Pendapat tersebut menyatakan bahwa cucu dapat mengganti posisi keahliwarisan orang tuanya yang lebih dahulu meninggal dari kakek untuk berhak mendapatkan harta warisan orang tuanya. Hal tersebut berbeda dengan penafsiran hukum waris pada umumnya, yang salah satunya tertuang dalam ketentuan kewarisan di Mesir, tidak dengan memberikan hak waris namun berupa wasiat wajibah. Tulisan ini bertujuan untukmengetahui latar belakang pendapat dan istinbath al hukmi yang digunakan oleh M. Yahya Harahap dalam menetapkan ahli waris pengganti. Dengan metode studi kritik terhadap berbagai bahan pustaka, ditemukan bahwa alasan penetapan ahli waris pengganti M. Yahya Harahap didasarkan pada hukum adat khususnya daerah Tapanuli Selatan, Sumatra Utara, dan dasar hukum yang digunakan yaitu 'Urf serta Istilah (Mashla $\underline{h}$ Mursalah) sebagai istinbath hukmi.
\end{abstract}

Kata Kunci :

istinbath al hukmi, hukum waris, wasiat wajibah, ahli waris pengganti

\section{Pendahuluan}

Hukum Islam, khususnya hukum waris diamalkan oleh umat Islam di Indonesia atas dasar kesadaran pribadi dan dorongan keimanan dan ketaatan terhadap agama Islam. Hukum ini menggunakan sumber utama Al-Quran dan Hadits, yang dilengkapi oleh ijtihad dan qiyas yang dilakukan oleh para ulama dan hakim. 
Berdasarkan Kompilasi Hukum Islam (KHI) pasal 171 huruf a, Hukum Kewarisan Islam (faraidl) adalah "..hukum yang mengatur tentang pemindahan hak oemilikian harta peninggalan (tirkah) pewaris, menentukan siapa-siapa yang berhak menjadi ahli waris dan berapa bagiannya masing-masing". Idris Djakfar dan Taufik Yahya mendefinisikan hukum kewarisan sebagai: ${ }^{1}$

"Seperangkat ketentuan yang membahas tentang cara-cara peralihan hak dari seseorang yang telah meninggal dunia kepada orang yang masih hidup yang ketentuan-ketentuan tersebut berdasarkan kepada Wahyu Illahi yang terdapat dalam Al-Qur'an dan penjelasannya yang diberikan oleh Nabi Muhammad SAW, dalam istilah arab disebut Faraidl".

Selain hukum Islam, masyarakat Indonesia juga menggunakan sistem kewarisan yang didasarkan pada hukum adat dan hukum Eropa, sehingga sistem hukum kewarisan di Indonesia bersifat plural (beraneka ragam). Sampai saat ini ketiga hukum tersebut masih dipergunakan.

Keanekaragaman budaya yang ada di Indonesia berpengaruh pada keragaman sistem hukum kkewarisan adat yang berlaku. Hal ini antara lain dipengaruhi oleh sifat kekerabatan berdasarkan keturunan. Setidaknya terdapat tiga sistem kekerabatan yang dikenal di Indonesia, yaitu sistem kewarisan individual, sistem kewarisan kolektif, dan sistem kewarisan mayorat. Sistem mayorat tersebut terbagi lagi ke dalam dua bentuk, yaitu mayorat laki-laki dan mayorat perempuan. ${ }^{2}$

Adapun sistem kewarisan Eropa berlaku di Indonesia sebagai akibat dari asas konkordansi hukum Perdata Barat yang tersusun dalam Burgerlijk Wetboek (BW) atau Kitab Undang-Undang Hukum Perdata (KUH Perdata). Hukum ini menganut sistem individual, dimana setelah pewaris meninggal dunia maka harta peninggalan dibagikan kepada masing-masing ahli waris untuk digunakan, dinikmati, atau bahkan dialih-hakkan kepada pihak lain. Ketentuan hukum waris dalam KUH Perdata diatur dalam Buku II titel 12 sampai 16.

KUH Perdata mengartikan hukum waris sebagai: "Kesemuanya kaedah hukum yang mengatur nasib kekayaan seseorang setelah ia meninggal dunia dan menentukan siapa orangnya yang dapat menerimanya". Setelah seseorang ada yang meninggal dunia dan meninggalkan harta kekayaan dari ahli waris yang berhak, maka atas harta peninggalan tersebut pewarisan baru akan dilaksanakan. Sebagaimana Pasal $830 \mathrm{KUH}$ Perdata menyatakan bahwa "pewarisan hanya berlangsung karena kematian. Sistem kewarisan menurut KUH Perdata mengikuti pada sistem keluarga inti dengan pembagian harta secara individual". Adapun ketentuan lebih lanjut mengenai kewarisan diatur dalam Pasal 1066 KUH Perdata.

\footnotetext{
${ }^{1}$ Idris Djakfar dan Taufik Yahya, Kompilasi Hukum Kewarisan Islam (Jakarta: PT. Dunia Pustaka Jaya, 1995). HIm. 3-4

${ }^{2}$ Soerjono Soekanto and Soleman b. Taneko, Hukum Adat Indonesia (Jakarta: CV. Garamada, 1981). HIm. 285-286
} 
Salah satu permasalahan yang muncul dalam hukum kewarisan adalah ahli waris pengganti. Ketiga hukum kewarisan tersebut di atas memiliki pandangan yang berbeda terhadap ahli waris pengganti. KUH Perdata khususnya pasal 854-857, mengatur secara tegas tentang penggantian tempat ahli waris (plaatsvervulling). Hukum adat pun mengenal ahli waris pengganti. Adapun dalam Al-Qur-an maupun Hadits, istilah ahli waris pengganti tidak secara tegas diatur. Dalam hal ini Allah menyerahkan kepada manusia untuk menentukan hukumnya. ${ }^{3}$

Istilah ahli waris pengganti yang digunakan di Indonesia tidak ditemukan di negara-negara Islam lainnya. Jalan yang ditempuh oleh negara-negara Islam seperti Mesir, menempuh jalan dengan lembaga wasiat wajibah. Ketika ahli waris meninggal terlebih dahulu daripada si pewaris, maka pembagiannya berpindah kepada ahli waris yang kedudukannya dapat digantikan oleh anak ahli waris. Ketentuan wasiat wajibah tercantum dalam kitab Undang-undang Wasiat Mesir Nomor 71 tahun 1946, pada pasal 76-79.Ketentuan mengenai pewaris pengganti di Indonesia telah diangkat dalam Kompilasi Hukum Islam (KHI). Salah satu pendukungnya adalah M. Yahya Harahap, seorang guru besar dan ahli di bidang Hukum Perdata dan anggota tim penyusun $\mathrm{KHI}$, sehingga pernyataannya bisa dijadikan sebagai acuan pelaksanaan hukum di Indonesia, tidak terkecuali hukum waris.

Pandangan beliau tentang ahli waris pengganti sangat menarik untuk dipelajari dan ditelusuri khususnya mengenai dasar atau latar belakang penetapan ahli waris pengganti baik dari sisi hukum positif maupun hasil istinbath al-hukmi yang dilakukan oleh M. Yahya Harahap tersebut.

\section{Metode Penelitian}

Penelitian ini menggunakan metode analisis kritis dengan menuturkan, menganalisa dan mengklasifikasikan pendapat $M$. Yahya Harahap tentang ahli waris pengganti, dengan metode ini diharapkan mendapat gambaran secara sistematis dan akurat mengenai fakta yang akan diteliti. Data yang digunakan dalam penelitian berdasal dari sumber data primer dan data sekunder yang dikumpulan dengan cara interview (wawancara), studi kepustakaan dan observasi. Wawancara yang penulis lakukan adalah wawancara terbuka, yaitu responden mempunyai kebebasan dalam mengutarakan jawabannya tanpa dibatasi oleh penulis. Dalam studi kepustakaan, dikumpulkan datadata atau teori-teori serta pedoman dari buku-buku yang berkaitan dengan masalah yang diteliti. Adapun observasi dilakukan sebagai pelengkap, yang dilakukan dengan cara mengamati dan mencatat secara sistematik fenomena-fenomena yang diteliti. ${ }^{4}$

Data yang telah terkumpul kemudian dianalisis menggunakan pendekatan kualitatif dengan teknik analisis isi (content analysis). Penganalisisan dilakukan dengan

\footnotetext{
${ }^{3}$ Amir Syarifudin, Hukum Kewarisan Islam (Jakarta: Kencana, 2008). HIm. 86

${ }^{4}$ Yaya Suryana and Tedi Priyatna, Metode Penelitian Pendidikan (Bandung: Sahifa, 2008). HIm. 71
} 
cara empat langkah utama. (a) menelaah semua data yang terkumpul dari sumber primer dan sumber skunder. (b) mengelompokkan seluruh data, (c) menghubungkan data dengan teori. (d) menafsirkan dan menarik kesimpulan dari data yang dianalisa.

\section{Penelitian dan Pembahasan (Penetapan Ahli Waris Pengganti)}

Dalam masyarakat Islam sering muncul perbedaan pendapat mengenai permasalahan agama di antara mereka, diantaranya masalah fiqh, baik dalam bidang ibadah, muamalah ataupun siyasah, salah satunya saja masalah ahli waris pengganti yang sampai saat ini masih ramai diperbincangkan di kalangan pelajar-pelajar di bidang Hukum Islam.

Berdasarkan hasil wawancara, M. Yahya Harahap menyatakan bahwa pertama, tentang penetapan ahli waris pengganti tidak terlepas dari hukum adat, karena suatu kenyataan ketika seseorang meninggal terlebih dahulu dari pewaris merupakan gejala yang hidup di dalam kehidupan manusia. Hal itu dengan sendirinya menimbulkan hubungan hukum antara seseorang yang meninggal terlebih dahulu dari pewaris. Ketika seseorang meninggal terlebih dahulu dari pewaris kemudian dia meninggalkan anak, maka anak tersebut ditetapkan sebagai ahli waris pengganti. ${ }^{5}$

Masyarakat adat mempunyai pengaruh yang sangat besar dalam tumbuhnya hukum yang berlaku di Indonesia, terutama terhadap ahli waris pengganti dimana ahli waris pengganti berhak mendapatkan harta waris dari ayah atau ibunya yang meninggal terlebih dahulu dari pewaris (kakek,nenek) oleh karena itu, ahli waris pengganti mendapatkan harta waris orang tuanya langsung dan tidak terhijab oleh siapapun akan tetapi ahli waris pengganti mendapatkan harta warisnya tidak boleh melebihi harta waris orang tuanya yang meninggal terlebih dahulu dari pewaris, sebagaimana kaidah fiqih:

"Adat kebiasaan dapat ditetapkan sebagai hukum"

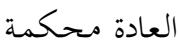

Di Tapanuli misalnya, pelaksanaan penentuan para ahli waris dalam hal penetapan ahli waris pengganti menggunakan garis pokok keutamaan dan penggantian. Dengan demikian dalam hal ini perlu memperhatikan prinsip garis keturunan yang dianut serta status perkawinan dari pewaris. Apakah belum menikah, pernah menikah, atau masih terikat dalam suatu perkawinan, dan status lainnya.

Ahli waris menurut garis pokok penggantian, seperti yang berlaku Tapanuli berdasarkan penuturan M. Yahya Harahap ialah "setiap orang dalam sekelompok keutamaan dengan syarat, bahwa antara dia dengan si-pewaris tidak ada penghubung atau tidak ada lagi penghubung yang masih hidup, yakni penghubung yang tidak ada lagi itu harus dalam sistem individual telah meninggal sebelum saat pembagian harta dan dalam sistem kolektif telah meninggal terlebih dahulu". ${ }^{6}$

\footnotetext{
${ }^{5}$ Wawancara dengan M. Yahya Harahap dilakukan pada (10 Mei 2012)

${ }^{6}$ Hazairin, Hukum Kewarisan Bilateral Menurut Qur'an dan Hadits (Jakarta : Tintamas, 1964), hlm 22 - 
Terlebih lagi di dalam KUH Perdata menjelaskan dalam pasal 854 sampai 857 menyatakan dengan jelas adanya Ahli waris pengganti (plaatsvervulling). Sehingga menurut M. Yahya Harahap penetapan ahli waris pengganti berasal dari pendekatan Hukum Eropa dan juga Hukum Adat yang sebagaimana tertera di dalam bukunya: ${ }^{7}$ Pelembagaan ahli waris pengganti (Plaatsvervulling) ke dalam Hukum Islam ini merupakan suatu terobosan terhadap penyelapan hak cucu atau harta warisan ayah apabila ayah lebih dulu meninggal dunia dari kakek.

Bebicara pelembagaan ini ada beberapa hal yang penting untuk dicatat seperti berikut ini:

1) Pelembagaannya melalui pendekatan kompromistis dengan hukum Adat atau nilai-nilai hukum Eropa.

2) Cara perkembangannya tidak mengikuti pendekatan berbelit melalui bentuk wasiat wajibah seperti yang dilakukan beberapa negara seperti Mesir.

Menurut Alyasa' Abubakar, "istilah penggantian tempat ini hanya dikenal dalam hukum Barat (BW) dan hukum adat, namun tidak dikenal dalam hukum Islam. Walaupun demikian, dengan adanya pembaharuan penafsiran hukum waris ini, istilah penggantian tempat pun kini sudah dibukukan dalam Kompilasi Hukum Islam, yang kini digunakan dalam setiap penyelesaian sengketa di Mahkamah Syar'iyah. ${ }^{\prime 8}$

Pendapat yang berbeda diutarakan Syahrizalyang menyatakan bahwa "jika dikaji secara mendalam, kitab fiqih klasik sebenarnya juga memberi peluang adanya pemberian saham waris kepada cucu walaupun konteksnya tidak sama dengan konteks hukum Adat". ${ }^{9}$

Nilai-nilai hukum adat secara nyata memberikan kemaslahatan dan kerukunan bagi masyarakat. Tidak ada larangan untuk menggunakan nilai-nilai hukum adat sebagai ketentuan hukum Islam. Sekiranya hal itu dicamkan atas alasan tidak dijumpai nashnya dalam Al-Qur'an dan Al-Hadits diperkirakan bisa menimbulkan kerusakan, oleh karena itu diperlukannya suatu ijtihad untuk memunculkan pendapat baru yang memberikan kemaslahatan.

Dalam pembentukan hukum Islam, para ulama sepakat menggunakan tiga sumber, yakni al-Qur'an, al-Hadist, dan ljtihad. Ijtihad menjadi sumber ketiga hal ini didasarkan hadist Nabi atas riwayat tentang pengutusan Mu'adz ibnu Jabal ke Yaman untuk menjadi Hakim, yang berbunyi:

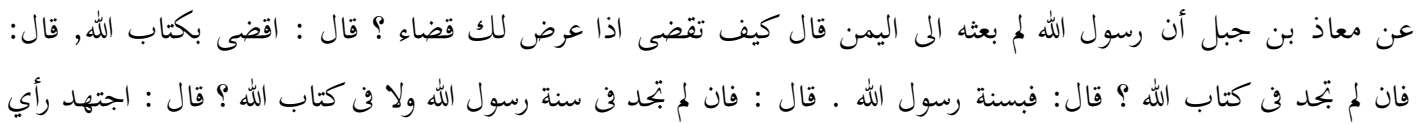

7 M. Yahya Harahap, Kedudukan Kewenangan dan Acara Peradilan Agama UU No. 7 Tahun 1989 (Jakarta: Sinar Grafika, 2003). HIm. 49-50

${ }^{8}$ Al Yasa' Abu Bakar, Ahli Waris Sepertalian Darah : Kajian Perbandingan Terhadap Penalaran Hazairin dan Penalaran Fikih Mazhab, (Jakarta : INIS, 1998.

${ }^{9}$ Ibid. Al Yasa Abu Bakar. 


$$
\begin{aligned}
& \text { ولا الو؟. فضرب رسو ل الله }
\end{aligned}
$$

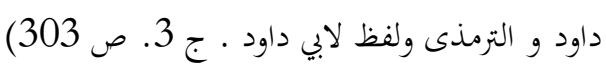

Dalam riwayat tersebut, Mu'adz ibnu Jabal berjanji akan menggunakan al-Qur'an dalam memutuskan sengketa. Apabila tidak terdapat ketentuannya dalam al-Qur'an ia akan menggunakan Hadist, dan apabila ia tidak mendapatkan dalam al-Qur'an dan alHadist maka ia akan berijtihad. ${ }^{10}$

Kedua, menurut M. Yahya Harahap pelembagaan ahli waris pengganti tidak mengikuti pelembagaan wasiat wajibah yang ada di negara-negara Islam lainnya. Memang negara-negara Islam yang menganut hukum Islam tidak mengakui adanya ahli waris pengganti, akan tetapi mengenal wasiat wajibah, yang dianut oleh negara Islam seperti Mesir. Oleh karena itu ahli waris pengganti merupakan hasil yang didapat dari mujtahidmujtahid Indonesia yang sudah tertuang dalam kompilasi hukum Islam, yakni ahli waris yang menggantikan orang yang meninggal dunia terlebih dahulu dari pewaris, dan bagian ahli waris pengganti sebesar bagian orang yang digantikannya. ${ }^{11}$

Serupa dengan Indonesia, negara Pakistan memakai sistem penggantian dalam ahli waris. Undang-undang Keluarga Muslim Pakistan menerapkan asas penggantian atas dasar pewarisan melalui hak. ${ }^{12}$ Dalam undang-undang tersebut dinyatakan bahwa dalam keadaan ada anak pewaris baik laki-laki maupun perempuan yang telah meninggal dan meninggalkan keturunan pada saat warisan akan dibagikan, maka anak-anak tersebut menerima bagian sama persis dengan yang seharusnya diterima orang tua mereka ${ }^{13}$

Namun demikian, mengenai pengganti ahli waris yang berlaku di Mesir, Maroko dan Suriah, cucu baik laki-laki maupun perempuan yang ayahnya atau ibunya wafat lebih dahulu daripada pewaris, dalam hal ini menerapkan konsep wasiat wajibah. Sedangkan di Indonesia, penetapan ahli waris pengganti dilakukan melalui pendekatan hukum Adat dan hukum Eropa.

Ketentuan tersebut diambil akibat sering munculnya keluhan dan pengaduan bahwa anak-anak (yatim) tidak mendapat warisan karena terhijab oleh saudara-saudara orang tuanya. Sering anak-anak tersebut hidup dalam kemiskinan sedang saudarasaudara ayahnya hidup berkecukupan. Memang, biasanya seseorang berwasiat untuk cucu yang yatim, namun ada pula yang meninggal sebelum melakukan wasiat tersebut. Karena itulah penetapan ahli waris pengganti menurut M. Yahya Harahap mengambil alih aturan yang tidak dikenal dalam mazhab-mazhab yang empat, ${ }^{14}$ namun diambil dari

${ }^{10}$ Dahyul Daipon, Metode ljtihad Ormas Islam (Refleksi Pluralisme Pemikiran Dalam Islam) Jurnal AlHurriyah, Vol. 10 No. 2, Juli Desember 2009, hlm. 39

${ }^{11}$ Pasal 185 Kompilasi Hukum Islam

12 Alyasa Abubakar, Ahli Waris Sepertalian Darah : Kajian Perbandingan Terhadap Penalaran Hazairin Dan Penalaran Figh MAdzhab (Jakarta: INIS, 1998). HIm. 242

${ }^{13}$ Al-Yasa Abu Bakar, hlm. 198

${ }^{14}$ M. Yahya Harahap, Kedudukan Kewenangan Dan Acara Peradilan Agama UU No. 7 Tahun 1989 (Jakarta: Sinar Grafika, 2003). HIm. 50 
'urf. 'Urf yang dijadikan dasar dalam pengakomodasian penetapan ahli waris pengganti ini adalah 'Urffi'li.

Dengan demikian penetapan ahli waris pengganti mengakomodir adat kebiasaan yang berkembang dalam masyarakat Indonesia tentang adanya penetapan ahli waris pengganti sebagai salah satu hukum yang berlaku di Indonesia sebagaimana yang sudah dirumuskan dalam $\mathrm{KHI}$ pasal 185 . Adat kebiasaan yang diakomodasi dalam penetapan ahli waris pengganti, berupa adat perkataan ('Urf Qauli) dan adat perbuatan ('Urf fi'li). Serta dalam KUH Perdata di dalam pasal 854 sampai 857 terdapat ahli waris pengganti (platsevervulling).

Ketiga, menurut M. Yahya Harahap tidak ada nash yang tegas baik di dalam AlQur'an maupun di dalam Hadist yang menyatakan adanya ahli waris pengganti. Menurut Soepomo munculnya institusi pergantian tempat ahli waris didasarkan pada pemikiran bahwa harta benda dalam keluarga sejak semula memang disediakan sebagai dasar material keluarga dan turunannya. ${ }^{15}$ Sehingga dalam beberapa masyarakat adat di Indonesia dikenal harta pusaka.

M. Yahya Harahap mengatakan bahwa penetapan penggantian ahli waris, untuk anak yang ditinggalkan oleh orang tuanya ketika orang tuanya meninggal terlebih dahulu dari pewaris (kakek,nenek) tidak diatur dalam Al-Qur'an maupun Al-Hadits dan begitu pula bukan berlandaskan pada An-Nisa ayat $33 .{ }^{16}$

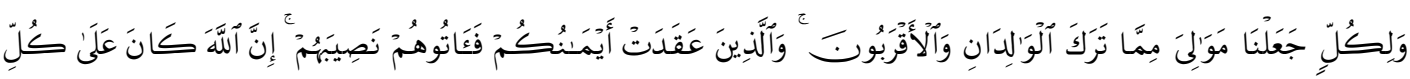

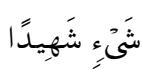

"Bagi tiap-tiap harta peninggalan dari harta yang ditinggalkan ibu bapak dan karib kerabat, Kami jadikan pewaris-pewarisnya, dan (jika ada) orang-orang yang kamu telah bersumpah setia dengan mereka, maka berilah kepada mereka bahagiannya. Sesungguhnya Allah menyaksikan segala sesuatu ". ${ }^{17}$

Karena menurutnya surat An-Nisa ayat 33 tersebut, yang dijadikan mawali adalah Ahli Waris dalam surat An-Nisa ayat 11 dan 12, sedangkan Ahli waris pengganti sama sekali tidak termasuk mawali dalam surat dan ayat tersebut.

Pandangan yang berbeda diutarakan oleh Hazairin sebagai hasil penafsiran Surat An-Nisa ayat 33 sebagai berikut:

"Dan untuk setiap orang itu aku Allah telah menggandakan mawali bagi harta peninggalan ayah dan emak bagi harta peninggalan keluarga dekat, demikian harta peninggalan bagi keluarga seperjanjianmu, karna itu bagikanlah kepada mereka bagian-bagian kewarisanya. ${ }^{18}$

\footnotetext{
${ }^{15}$ Ibid. Al-Yasa Abu Bakar

${ }^{16}$ M. Yahya Harahap, wawancara oleh Aang Abdul Aziz. tanggal 10 Mei 2012

${ }^{17}$ Departemen Agama. Al-Qur'an dan Terjemahnya. Dipenogoro. 2005.

18 Moh. Dja'far, Polemik Hukum Waris (Perdebatan Antara Prof. Dr. Hazairin Dan Ahlu Sunnah) (Jakarta: Kencana Mas, 2007). HIm 31
} 
Dalam penafsiran di atas tergambar dengan jelas bahwa nasibahun (bagian mereka) harus diberikan kepada mawali, bukan kepada orang yg termasuk likullin, karena mawali itu adalah ahli waris. ${ }^{19}$ Agar mudah ditangkap maksud dari surat an-Nisa : 33 maka lafad likullin diganti dengan lifullanin, dan ja'alna diganti jadi ja'alallah, maka bunyi ayat itu menjadi: ${ }^{20}$

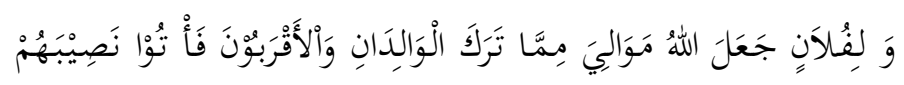

"Bagi fulan, Allah menjadikan mawali sebagai ahli waris terhadap harta peninggalan kedua orang tua dan keluarga dekat, maka berikan kepada mereka bagian mereka"

Pengertian ayat mawali itu dapat dijelaskan sebagai berikut: jika ayah atau ibu yang mati, maka sesuai istilah yang mempunyai padanan, maka anaklah yang menjadi ahli warisnya, baik anak yang masih hidup, maupun yang sudah meninggal si pulan umpamanya, yang Allah menjadikan mawali si pulan sebagai penggantinya untuk menerima harta warisnya. Jelas di sini ayah atau ibu itu pewaris, si pulan adalah anak ayah dan ibu yang juga keturunan mereka, tetapi sudah meninggal, sedang mawali si pulan juga keturunan ayah dan ibu tapi bukan anak. Jika si pewaris tidak meninggalkan anak, tidak juga orang tua, tetapi meninggalkan saudara, maka si pewaris adalah aqrabun yang diwarisi oleh aqrabun pula atau oleh mawali aqrabun itu, mungkin di situ juga ada ululqurban yang tidak mewarisi. Jadi dalam penggantian ini ada yang meninggal lebih dahulu, dan mawali itu adalah ahli waris pengganti. ${ }^{21}$

Kemudian, kitab Khulasah 'ilmi al-faraid yang dikarang oleh Muhammad al-Amien al-Asyri yang dikemukakan oleh Isma'il muhammad Syah menyampaikan penggantian pewaris sebagai berikut: ${ }^{22}$

"Yang dapat menggantikan orang lain dalam warisan adalah : (a) Anak laki-laki dari anak laki-laki adalah seperti anak laki-laki hanya dia tidak dapat dua kali bagian bersama anak perempuan. (b) Anak perempuan dari anak laki-laki adalah seperti anak perempuan, kecuali dapat terhalang dengan adanya anak laki-laki. (c) Nenek perempuan adalah seperti ibu, hanya ia tidak dapat menerima $1 / 3$ atau $1 / 3$ sisa. (d) Kakek adalah seperti ayah, kecuali ia tidak dapat menghalangi saudara seibu sebapak, dan saudara seayah. (e) Saudara laki-laki seayah adalah seperti saudara seibu seayah, kecuali ia tidak menerima dua kali banyakknya bersama saudara perempuan seayah. (f) Saudara perempuan seayah adalah seperti saudara perempuan seibu seayah, kecuali ia dapat terhalang dengan adanya saudara lakilaki seibu seayah".

\footnotetext{
${ }^{19}$ Fenky Permadhi, Studi Pasal 185 Kompilasi Hukum Islam Tentang Waris Pengganti (Sebuah Tinjauan Mashlahah), Universitas Islam Negeri Maliki Malang, 2011, hlm. 66

${ }^{20}$ Departemen Agama RI, Mushaf Al-Qur'an Terjemah (Jakarta : al-Huda, 2005) hlm. 84

${ }^{21}$ Hazairin, Hukum Kewarisan Bilateral Menurut Qur'an Dan Hadith (Jakarta: Tintamas, 1964). HIm. 29

${ }^{22}$ Siah Khosyi'ah, hlm. 123
} 
Masalah penggantian cucu menempati kedudukan anak sebagai ahli waris pengganti ini didasarkan atas ucapan sahabat Nabi ahli bidang fara'id yaitu Zaid bin Tsabit berkata:

$$
\text { كال زيـد : ولد الأ بناء بمنزلة الولد إذا لم يكن دونهم ولد ذكره كذ كرهم وأ نثاهم; كانثاهم ير ثون كما ترثون ويجبون }
$$

"Zaid berkata: "Seorang cucu kedudukannya sama dengan seorang anak, jika tidak ada selain mereka maka anak laki-lakinya seperti anak laki-lakinya, dan seorang perempuan seperti anak perempuannya, mereka dapat menerima warits seperti seorang anak yang dapat menerima warits, dan mempunyai kewajiban sebagaimana kewajibannya, dan seorang cucu tida dapat menerima warits selama masih ada anak"

Cucu perempuan dari anak laki-laki sebagai penyelesaiannya dan berfungsi sebagai pengganti, ketika bersama-sama dengan anak perempuan satu orang, maka cucu tersebut akan memperoleh bagian 1/6 untuk menyempurnakannya 2/3 jika bersama dengan saudara, ketentuan ini memberikan kemungkinan saudara mendapatkan asobah. ${ }^{23}$ Permasalahan ini didasarkan pada hadist dari lbn Mas'ud yang berbunyi:

$$
\text { عن ابن مسعود قال : قضى النبي ص م. للأ بنية النصف و لأ بنية ابن السدس تكملة الثلثين وما بقي فلأخت }
$$

Persoalan kakek dari bapak dalam kedudukannya menggantikan bapak, disandarkan atas pemahaman terhadap surat Yusuf ayat 38. Dalam ayat ini Allah menisbatkan Ibrahim, Ishaq dan Yakub dengan bapak padahal mereka kakek-kakenya, begitu pula dalam ilmu waris masalah kakek di qiyaskan dengan bapak sehingga kakek sama dalam bapak menempati kedudukan bapak dikala bapak telah meninggal terlebih dahulu. ${ }^{24}$

Sebagaimana menurut A. Wasit Aulawi sebagaimana dikutip oleh Amarullah Ahmad mengatakan bahwa "...yang dinamakan dengan ahli waris pengganti adalah menempatkan seseorang ahli waris, yang selama ini dipandang tidak atau belum berhak menerima harta waris, ke dalam golongan ahli waris yang berhak menerima harta waris. Oleh karena itu ahli waris pengganti tidak menempati kedudukan penuh seperti ahli waris yang digantikannya, sehingga ahli waris pengganti tidak akan merugikan ahli waris yang setingkat dengan ahli waris yang digantikannya." ${ }^{25}$

Permasalahannya, sering ahli waris pengganticenderung merusak hubungan antar angota keluarga. Karena merasa memiliki status hukum yang kuat sebagai ahli waris, ahli waris pengganti kemudian menggugat ahli waris utama yang merupakan paman atau bibi mereka, akibat harta waris tidak kunjung dibagikan. Ahli waris pengganti juga didapat dari perluasan makna, seperti pengertian anak diperluas kepada keturunannya

\footnotetext{
${ }^{23}$ Siah Khosyiah, hlm. 124

${ }^{24}$ Ibid

${ }^{25}$ Ahmad Amarullah dkk, Dimensi Hukum Islam Dalam Sistem Hukum Nasional (Jakarta: Gema Insani, 1996). HIm. 63-64
} 
atau cucu, begitu pula dengan pengertian ayah diperluas kepada kakek, dan seterusnya. ${ }^{26}$

Keempat, perkembangan hukum waris dalam Islam mengarah pada fungsi harta warisan sebagai sarana untuk meningkatkan ekonomi ahli waris.

Menurut M. Yahya Harahap apabila ahli waris pengganti tidak termasuk ke dalam ahli waris apakah adil?

"Pelembagaan waris pengganti didasarkan atas rasa keadilan dan prikemanusiaan.

Tidak layak, tidak adil, dan tidak manusiawi menghukum seseorang dengan tidak berhak menerima warisan yang semestinya harus diperoleh oleh ayahnya, hanya ada faktor kebetulan ayahnya lebih dulu meninggal dari kakek. Apabila jika hak ini dikaitkan dengan fakta, pada saat kakek meninggal, anak-anaknya semua sudah kaya dan mapan. Sebaliknya si cucu oleh karena ditinggal yatim, melarat, dan miskin. Apakah patut melenyapkan haknya untuk memperoleh apa yang semestinya menjadi bagian bapaknya?" ${ }^{27}$

Penulis sependapat karena masyarakat Indonesia lebih dominan mengikuti sistem kekeluargaan bilateral/parental. Masyarakat adat Indonesia pada umumnya hidup dalam keluarga besar (extended family) dengan sifat komunalnya, dan gotong-royong, dimana setiap anggota keluarga saling menyokong dan membantu. Anggota keluarga yang mampu wajib membantu anggota keluarga yang kekurangan atau belum mampu. Namun tidak saat ini, ketika sikap individualistis mempengaruhi kehidupan masyarakat, sehingga budaya tolong menolong antar saudara menjadi hilang, dan lebih mengutamakan keluarga inti (nucliear family) atau batih. yang hanya terdiri dari ibu, ayah, dan anak saja. Sehingga keponakan atau saudara yang tidak mampu tidak menjadi tanggungannya. Atas alasan tersebut, konsep ahli waris pengganti menjadi relevan dalam kondisi masyarakat saat ini.

Dari segi lain hubungan antara cucu dengan kakek atau nenek yang diikat oleh kasih sayang murni, cinta kasih kakek atau nenek terhadap cucunya, asas keadilan yang dijunjung tinggi oleh Agama Islam dan Adat Indonesia, menjadi beberapa pertimbangan sehingga secara moral kakek atau nenek dituntut memberikan harta ayahnya kepadanya untuk kesejahtraan cucunya. Maka seyogyanya saudara-saudara ayahnya bersedia memberikan harta warisan ayahnya kepadanya yang pantas dari harta orang tuanya yang meninggal terlebih dahulu.

Menurut M. Yahya Harahap apabila hak cucu atas harta warisan ayah atau ibu apabila ayah atau ibu lebih dulu meninggal dari kakek, karena orangtuanya furudh al muqaddrah yang digantikan oleh anaknya sebagai furudh al muqaddrah, maka berlakulah ahli waris pengganti, oleh karena itu menurut penulis ahli waris pengganti merupakan tindakan alternatif yang memberikan mashlahat.

26 Junaedi Kadir, diakses tanggal, o6 Juni 2013, "Kedudukan Ahli Waris Pengganti dalam Tinjauan Hukum Perdata dan Hukum Islam" https://junetbungsu.wordpress.com/2013/03/13/kedudukan-ahli-warispengganti-dalam-tinjauan-hukum-per-data-dan-hukum-islam.

${ }^{27}$ M. Yahya Harahap. HIm. 49-50 
Sementara itu cucu adalah generasi penerus kakeknya di suatu saat nanti, saat kakek meninggal cucunya sudah menjadi anak yatim terlebih dahulu, karena ayahnya terlebih dahulu meninggal sehingga untuk pantas cucu diberikan harta warisannya dari kakek agar dalam segi moral cucu terbantu ekonominya bukan saja dari segi materil tetapi dari segi moral (kebahagiaan) sehingga cucu mendapatkan kebahagiaan dalam keluarga.

Menurut penulis apabila suatu saat kakek meninggal kemudian cucunya sudah yatim terlebih dahulu tidak mendapatkan harta peninggalan orang tuanya maka itu tidak adil mencampakan cucunya menjadi melarat, hartanya hanya jatuh kepada saudarasaudara ayahnya, dan tidak adil bila menghapuskan kedudukan hak waris mewarisi kepada ayahnya, karena ayahnya sudah meninggal terlebih dahulu dari kakek.

Adapun yang berwenang untuk melaksanakan penetapan ahli waris pengganti tersebut adalah Hakim Pengadilan Agama. Dengan demikian Hakim Pengadilan Agama berwenang untuk memaksa memberi putusan wajib kepada cucu atas semua warisan ayah apabila ayah lebih dulu meninggal dari kakek demi kepentingan mereka. Sebagaimana kaidah fiqhiyah mengatakan: ${ }^{28}$

$$
\text { إن لو لي الأمر أن يأمر بالمباح لما يراه من المصلحة العآ مة ومتى أمر به وجبت طاعته }
$$

"Pemegang kekuasaan mempunyai wewenang memerintahkan perkara yang mubah, karena berpendapat bahwa hal itu akan membawa kemaslahatan umum.

Bila penguasa memerintahkan demikian, wajiblah ditaati"

Memberikan hak ahli waris pengganti kepada cucu akan membawa kemaslahatan kepada semua pihak baik kepada cucu, saudara ayahnya dan juga kakeknya. Karena hak cucu terpenuhi dan hak saudara-saudara ayahnya terpenuhi sebagai ahli waris tetap diberikan. Sebaliknya apabila tidak diberi hak melalui ahli waris pengganti akan menimbulkan konflik, disatu pihak cucu yang orangtuanya meninggal terlebih dahulu menuntut haknya sedang di pihak lain ahli waris saudara-saudara orangtuanya tidak mau memberikan, akhirnya terjadi persengketaan antara mereka sehingga menimbulkan kemadharatan. Sesuatu yang menimbulkan kemadharatan harus dihilangkan sebagaimana kaidah fiqih:

"Kemadharatan itu harus dilenyapkan" 29 الضرر يزال

Berdasarkan pernyataan tersebut, maka Hakim Pengadilan Agama berhak memberi putusan wajib ahli waris pengganti untuk tujuan kemaslahatan bagi para pihak yang bersengketa, yang dalam hal ini disebut mashlaha $\underline{h}$ mursalah, yaitu kemashlahatan yang bersifat umum dan tidak memiliki dalil yang tegas dalam Al-Quran dan Hadits. ${ }^{30}$

${ }^{28}$ Fathurrahman Djamil, Penyelesaian Pembiayaan Bermsalah Dibank Syariah (Jakarta: Sinar Grafika, 2014). HIm. 65

${ }^{29}$ Shalih Ibn Ghanim as-Sadlan, Al-Qawaid Al-Fiqhiyyah al-Kubra, (Riyadh: Dar al-Balansiyyah, $1417 \mathrm{H}$ ) hal. 498.

${ }^{30}$ Abû Hamid Muhammad ibn Muhammad ibn Muhammad al-Ghazali, al-Manhûl min Ta'lîqât al-Usûl, (Damaskus : Dâr al-Fikr, 1980) hlm. 355 
Berkenaan dengan cucu tidak terhijab ahli waris yang lain (saudara-saudara ayah atau ibunya), karena menggantikan posisi ayah atau ibunya yang meninggal sebelum kakek, bukan termasuk maslahạ muulghah, karena dapat diketahui bahwa cucu menggantikan posisi ayah atau ibunya sebagai furudh al muqâddarah, tidak terputus hubungan nasab sehingga masing-masing mendapat bagian dari harta peninggalan dan bagian ahli waris didapatkan sesuai dengan ketentuan dalam hukum kewarisan Islam, hukum kewarisan adat, dan KUH perdata. Demikian juga cucu tidak terhijab bagiannya dan tidak menghijab pula ahli waris dari mendapatkan harta warisan. Hal ini sejalan dengan ketentuan yang ditentukan oleh $\mathrm{KHI}$ pasal 185 dan juga menurut M. Yahya Harahap yang berbunyi: ${ }^{31}$

"(a) bagian Ahli waris pengganti tidak boleh melebihi bagian ahli waris yang sederajat dengan yang diganti. (b) Jika kalau waris pengganti seorang saja, dan ayahnya hanya mempunyai seorang saudara perempuan, agar bagiannya sebgai waris pengganti tidak lebih besar bagian saudara perempuan ayahnya, harta warisan antara waris pengganti dengan bibinya."

Menurut penulis dalam hal cucu menggantikan posisi orang tua yang lebih dulu meninggal dengan konsep ahli waris pengganti adalah kuat, kalau seandainya memakai konsep wasiat wajibah sangatlah lemah dan perhitungannya berbelit. Alasannya, pertama: memadharatkan ahli waris, maksudnya bagiannya menjadi bekurang dari yang seharusnya mereka terima, setelah diamalkan wasiat wajibah $1 / 3$ dari harta peninggalan untuk cucu dan sisanya diberikan kepada ahli waris. Dalam hal ini tentunya tidak adil bagi ahli waris kalau bagiannya itu berkurang, karena pada asalnya cucu itu terhijab oleh anak laki-laki.

Kedua: bagian $1 / 3$ dari harta peninggalnya sifatnya adalah mutlak. Maksudnya apabila harta peninggalan yang diberikan kepada cucu kurang dari 1/3 maka cucu dapat mengajukan gugatan kepada pengadilan, karena bagian tersebut sudah menjadi ketentuan suatu undang-undang yang bersifat menggikat dan memaksa.

Ketiga: cucu adalah masih keturunan (nasab) dari kakeknya, oleh karena itu cucu berhak mendapatkan bagian furudh al muqaddarah orang tuanya yang meninggal lebih dahulu atau dapat menggantikan kedudukan bagian orang tuanya, akan tetapi bagiannya tidak boleh melebihi bagian para ahli waris. Apabila cucu dapat menggantikan kedudukan bagian orang tuanya maka cucu laki-laki pancar laki-laki mendapatkan harta peninggalan Rp. 2.000.000. berbeda dengan saudara ayahnya yang perempuan Rp. 1.000.000 karena bagian saudara perempuannya mendapatkan 1/3. Guna mencapai kemaslahatan, bagian ahli waris pengganti tidak boleh melebihi bagian ahli waris yang sederajat dengan yang diganti. Maka harta warisnya dibagi dua, untuk ahli waris pengganti mendapatkan 1.500.000 dan untuk anak perempuan mendapatkan 1.500.000, agar tidak ada pertikaian didalam keluarga, agar tercapai kemaslahatan.

\footnotetext{
${ }^{31}$ M. Yahya Harahap. HIm. 49-50
} 


\section{Simpulan}

Penetapan ahli waris pengganti di Indonesia merupakan hasil istimbath hukmi istishlah (Mashalah mursalah) yang merupakan hasil dari pengkompromian antara hukum Islam, hukum Adat dan hukum Eropa. Menurut M. Yahya Harahap penggalian hukum tersebut didasarkan terutama pada hukum adat ('Urf) dengan kaidah fiqih yang berbunyi al-'adah muhakkamah. Hal tersebut karena ketentuan ahli waris pengganti untuk ahli waris yang menggantikan orang yang meninggal dunia lebih dulu dari pewaris, dan bagian ahli waris digantikan sebesar bagian orang yang digantikan, tidak dijumpai dalam nash Al-Qur'an dan Al-Hadits maupun dalam ajaran kitab-kitab fiqih, dan pada surat AnNisa ayat 33 .

Nilai hukum adat yang diambil dalam hal ini adalam Hukum Adat daerah Tapanuli Selatan yang dipadukan dengan ketentuan dalam KUH Perdata (Burgerlijk Wetboek) khususnya pasal 841 dan 842 . Kedua sumber hukum tersebut yang kemudian menjadi bahan pengaya pembentukan pasal 185 Kompilasi Hukum Islam, dan sampai saat ini menjadi dasar dalam pengambilan keputusan di Pengadilan Agama.

\section{Daftar Pustaka}

Al-Ghazali, Abû Hamid Muhammad ibn Muhammad ibn Muhammad, 1980. al-Manhûl min Ta'lîqât al-Usûl, Damaskus : Dâr al-Fikr, 1980

Amarullah, Ahmad dkk, 1996. Dimensi Hukum Islam Dalam Sistem Hukum Nasional Jakarta: Gema Insani, 1996.

Bakar, Alyasa Abu, 1998. Ahli Waris Sepertalian Darah : Kajian Perbandingan Terhadap Penalaran Hazairin Dan Penalaran Fiqh MAdzhab. Jakarta: INIS.

Departemen Agama RI, 2005. Mushaf Al-Qur'an Terjemah Jakarta : al-Huda Departemen Agama, 2005. Al-Qur'an dan Terjemahnya. Dipenogoro : T.Pn.

Dja'far. Moh. 2007. Polemik Hukum Waris (Perdebatan Antara Prof. Dr. Hazairin Dan Ahlu Sunnah). Jakarta: Kencana Mas.

Djakfar, Idris dan Yahya, Taufik. 1995. Kompilasi Hukum Kewarisan Islam. Jakarta: PT. Dunia Pustaka Jaya.

Djamil, Fathurrahman. 2014. Penyelesaian Pembiayaan Bermsalah Dibank Syariah. Jakarta: Sinar Grafika.

Harahap, M. Yahya. 2003. Kedudukan Kewenangan dan Acara Peradilan Agama UU No. 7 Tahun 1989. Jakarta: Sinar Grafika.

Hazairin, Hukum Kewarisan Bilateral Menurut Qur'an dan Hadits (Jakarta : Tintamas, 1964)

Sadlan. Shalih Ibn Ghanim as-. 1417. Al-Qawaid Al-Fiqhiyyah al-Kubra, Riyadh: Dar alBalansiyyah

Soekanto, Soerjono dan Taneko, Soleman b.. 1981. Hukum Adat Indonesia. Jakarta: CV. Garamada.

Suryana, Yaya dan Priyatna, Tedi. 2008. Metode Penelitian Pendidikan. Bandung: Sahifa. Syarifudin, Amir, 2008. Hukum Kewarisan Islam. Jakarta: Kencana. 
Daipon, Dahyul. 2009. Metode ljtihad Ormas Islam (Refleksi Pluralisme Pemikiran Dalam Islam) Jurnal Al-Hurriyah, Vol. 10 No. 2, Juli Desember 2009,

Harahap, M. Yahya. (Penulis) wawancara oleh Aang Abdul Aziz, dilakukan pada Tanggal 10 Mei 2012

Permadhi, Fenky, Studi Pasal 185 Kompilasi Hukum Islam Tentang Waris Pengganti (Sebuah Tinjauan Mashlahah), Universitas Islam Negeri Maliki Malang, 2011

Kadir, Junaedi. (2013, Juni 6) Kedudukan Ahli Waris Pengganti dalam Tinjauan Hukum Perdata dan Hukum Islam, diakses melalui https://junetbungsu.wordpress.com /2013/03/13/kedudukan-ahli-waris-pengganti-dalam-tinjauan-hukum-per-data-dan -hukum-islam. 